\title{
Moss stable isotopes (carbon-13, oxygen-18) and testate amoebae reflect environmental inputs and microclimate along a latitudinal gradient on the Antarctic Peninsula
}

\author{
Jessica Royles ${ }^{1,3} \cdot$ Matthew J. Amesbury $^{2}$ Thomas P. Roland ${ }^{2}$ - Glyn D. Jones ${ }^{3}$ • \\ Peter Convey $^{1} \cdot$ Howard Griffiths $^{3} \cdot$ Dominic A. Hodgson $^{1} \cdot$ Dan J. Charman ${ }^{2}$
}

Received: 22 May 2015 / Accepted: 8 March 2016 / Published online: 22 March 2016

(C) The Author(s) 2016. This article is published with open access at Springerlink.com

\begin{abstract}
The stable isotope compositions of moss tissue water $\left(\delta^{2} \mathrm{H}\right.$ and $\left.\delta^{18} \mathrm{O}\right)$ and cellulose $\left(\delta^{13} \mathrm{C}\right.$ and $\left.\delta^{18} \mathrm{O}\right)$, and testate amoebae populations were sampled from 61 contemporary surface samples along a $600-\mathrm{km}$ latitudinal gradient of the Antarctic Peninsula (AP) to provide a spatial record of environmental change. The isotopic composition of moss tissue water represented an annually integrated precipitation signal with the expected isotopic depletion with increasing latitude. There was a weak, but significant, relationship between cellulose $\delta^{18} \mathrm{O}$ and latitude, with predicted source water inputs isotopically enriched compared to measured precipitation. Cellulose $\delta^{13} \mathrm{C}$ values were dependent on moss species and water content, and may reflect site exposure to strong winds. Testate amoebae assemblages were characterised by low concentrations and taxonomic diversity, with Corythion dubium and Microcorycia radiata types the most cosmopolitan taxa. The similarity between the intraand inter-site ranges measured in all proxies suggests that microclimate and micro-topographical conditions around the moss surface were important determinants of proxy values.
\end{abstract}

Communicated by David R. Bowling.

Electronic supplementary material The online version of this article (doi:10.1007/s00442-016-3608-3) contains supplementary material, which is available to authorized users.

Jessica Royles

jr328@cam.ac.uk

1 British Antarctic Survey, High Cross, Madingley Road, Cambridge CB3 OET, UK

2 Geography, College of Life and Environmental Sciences, University of Exeter, Exeter EX4 4RJ, UK

3 Department of Plant Sciences, University of Cambridge, Downing Street, Cambridge CB2 3EA, UK
Isotope and testate amoebae analyses have proven value as palaeoclimatic, temporal proxies of climate change, whereas this study demonstrates that variations in isotopic and amoeboid proxies between microsites can be beyond the bounds of the current spatial variability in AP climate.

Keywords Climate change - Precipitation - Water line · Assemblage $\cdot$ Microtopography

\section{Introduction}

The Antarctic Peninsula (AP) has experienced significant climate change over the past 50 years, with increasing temperatures and changing precipitation patterns (Turner et al. 2005, 2009, 2014). The area of ice-free land has increased (Arigony-Neto et al. 2009; Cook et al. 2005), the depth and continuity of permafrost have altered (Bockheim et al. 2013) and the melt season has lengthened (Barrand et al. 2013). Consequently, the microhabitats of native terrestrial flora and fauna have changed (Parnikoza et al. 2009; Royles et al. 2013a). An equally dynamic future is predicted, with increased potential for successful establishment by nonnative species, alongside expansion of native populations (Chown et al. 2012; Convey 2011; Larsen et al. 2014).

Little is known about the responses of terrestrial biological systems to climate change during the short summer growing season (Convey 2010). Moss is widespread across ice-free areas of the AP and occasional deep moss banks provide rare terrestrial biological archives of environmental changes, spanning timescales up to 5000 years (Björck et al. 1991; Royles et al. 2012). Peat accumulation rates, mineral composition and extent of humification have been interpreted as temperature- and moisture-driven environmental proxies (Björck et al. 1991; Fenton 1980). More recently, the 
stable carbon $(\mathrm{C})$ isotope composition $\left(\delta^{13} \mathrm{C}\right)$ of cellulose has been used as a proxy for the carbon dioxide $\left(\mathrm{CO}_{2}\right)$ assimilation rate (Royles et al. 2012), whilst testate amoebae provide an indication of microbial activity (Royles et al. 2013a).

Ombrotrophic mosses are dependent on precipitation and the isotopic composition of this source water $\left(\delta^{18} \mathrm{O}_{\mathrm{SW}}\right)$ is an important determinant of moss cellulose composition $\left(\delta^{18} \mathrm{O}_{\mathrm{C}}\right)$ (Barbour 2007). Cellulose is the major degradation-resistant component of bryophyte organic matter and is therefore a potential palaeoclimate archive. Understanding the relationship between $\delta^{18} \mathrm{O}_{\mathrm{SW}}$ and the composition of leaf water $\left(\delta^{18} \mathrm{O}_{\mathrm{L}}\right)$ during cellulose synthesis is essential for reconstructing $\delta^{18} \mathrm{O}_{\mathrm{SW}}$ from preserved cellulose as $\delta^{18} \mathrm{O}_{\mathrm{L}}$ is frequently isotopically enriched compared to $\delta^{18} \mathrm{O}_{\mathrm{SW}}$ (Barbour 2007). Being poikilohydric, moss water content can be highly variable over short time periods, although mosses may be metabolically active only during a narrow range of conditions. Thus, $\delta^{18} \mathrm{O}_{\mathrm{L}}$ at most reflects the isotopic composition of precipitation between two dry periods and is essentially a short-term indicator, whilst $\delta^{18} \mathrm{O}_{\mathrm{C}}$ integrates ${ }^{18} \mathrm{O}$ inputs and exchanges throughout the period of growth.

For mosses, external water is a critical component of metabolism as it limits the $\mathrm{CO}_{2}$ diffusion rate from atmosphere to chloroplast. Photosynthetic $\mathrm{CO}_{2}$ assimilation and associated $\mathrm{C}$ isotope discrimination profiles initially increase as external water evaporates and then decline as tissues subsequently desiccate and metabolism ceases (Rice and Giles 1996; Royles et al. 2013b; Williams and Flanagan 1996). As a proportion of assimilated $\mathrm{C}$ is used to synthesise cellulose, the $\mathrm{C}$ isotope ratio of moss cellulose $\left(\delta^{13} \mathrm{C}_{\mathrm{C}}\right)$ is a good proxy for conditions during photosynthesis (Royles et al. 2012).

Changes in testate amoebae populations are widely used as a palaeohydrological proxy in temperate peatlands (Mitchell et al. 2008) and the proxy has recently been applied to the AP (Royles et al. 2013a). Temperature, moisture, $\mathrm{pH}$ and biogeographical factors all influence the contemporary distribution and population dynamics of mossdwelling testate amoeba around Antarctica (e.g. Mieczan and Adamczuk 2014; Smith 1992, 1996; Todorov and Golemansky 1999). Populations are dominated by small, cosmopolitan taxa such as Corythion, Trinema and Euglypha spp., with diversity generally lower than in temperate regions (Smith 1992). Testate amoebae are dominant heterotrophic organisms in peatlands (Gilbert et al. 1998; Jassey et al. 2013; Mitchell et al. 2003) so their biomass and concentration can be used to assess microbial community responses to external drivers (Ju et al. 2014; Mitchell 2004; Payne and Mitchell 2009). Rapid population growth was coincident with recent AP climate change, suggesting that temperature, through its influence on food availability and reproduction rate, is a primary driver of microbial activity (e.g. Royles et al. 2013a). However, previous research on the effect of temperature on testate amoeba in temperate and sub-Arctic peatlands is uncertain and contradictory (Jassey et al. 2013; Payne 2014; Tsyganov et al. 2012).

Ecosystem responses over time, at two trophic levels, to AP climate change can be detected using multi-proxy analysis (peat accumulation rate, $\delta^{13} \mathrm{C}$, testate amoebae) of mosspeat cores (Royles et al. 2013a). Here, using contemporary Chorisodontium aciphyllum and Polytrichum strictum surface samples from four sites over a $>600-\mathrm{km}$ latitudinal gradient, we measure the modern analogues of these palaeoclimate proxies $\left(\delta^{13} \mathrm{C}_{\mathrm{C}}, \delta^{18} \mathrm{O}_{\mathrm{C}}\right.$, moss tissue water $\delta^{18} \mathrm{O}$ and $\delta^{2} \mathrm{H}$, testate amoebae assemblages). Our primary aim is to test these against measurements of precipitation stable isotope composition, tissue water content and (micro-)climate in order to investigate the response of moss and amoebae to environmental and climate gradients, to test their applicability in palaeoclimate studies. This provides vital context to understand the contemporary processes driving the proxy signals, which are preserved over thousands of years in the moss bank core samples. Our hypotheses are that:

1. Moss water and cellulose $\delta^{18} \mathrm{O}$ values are recorders of precipitation isotope ratios.

2. Cellulose $\delta^{13} \mathrm{C}$ is a record of photosynthetic assimilation and growing season length with lower latitude sites discriminating more against ${ }^{13} \mathrm{C}$.

3. Across the latitudinal gradient, testate amoeba community composition diversifies, and concentration and biomass increase, as a result of higher temperatures and/or increases in water availability.

\section{Materials and methods}

\section{Sample sites}

During January 2012 and January 2013, sixty-one sites on the western AP, divided between Green Island (GRE), Norsel Point (NOR), Ardley Island (ARD) and Elephant Island (ELE) (Fig. 1; Table S1) were visited. Surface moss samples $(5 \mathrm{~cm} \times 5 \mathrm{~cm} \times 5 \mathrm{~cm})$, water samples ( $>1 \mathrm{ml}$, snow banks, fresh precipitation, water pools) and short-term temperature measurements (Fig. 2) were collected. Water samples were also collected opportunistically from other AP locations (Table S2). Moss tissue and water samples were stored frozen until analysis. Tissue moisture content [(fresh mass - dry mass)/dry mass] and bulk density (Table S1) were determined by excising ca. $1-\mathrm{cm}^{3}$ cuboids from each frozen moss sample which were precisely measured and dried to a constant mass.

\section{Isotope analyses of water and cellulose}

$\delta^{18} \mathrm{O}$ and $\delta^{2} \mathrm{H}$ isotope ratios of source waters were determined using cavity ring-down spectroscopy (Lis et al. 


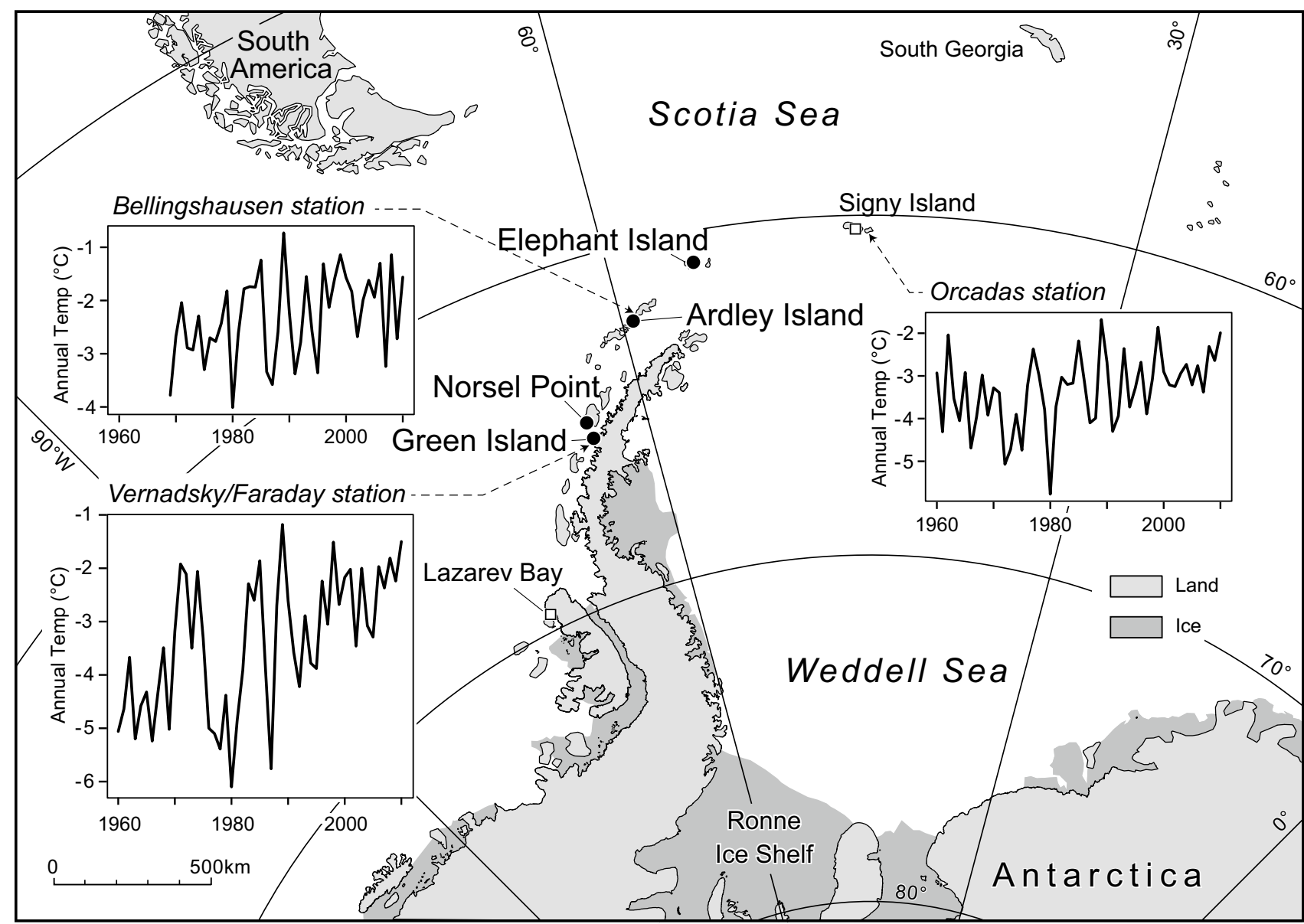

Fig. 1 Map of Antarctic Peninsula (AP) region with new sample sites marked (black circles). Other relevant sites are shown (white squares). Inset graphs show mean annual temperature records since
1960 from Orcadas (South Orkney Islands), Bellingshausen (South Shetland Islands) and Vernadsky/Faraday (Argentine Islands) stations

sodium chlorite, $10 \mathrm{ml}$ glacial acetic acid, 11 deionised water) in a $70{ }^{\circ} \mathrm{C}$ water bath. For $\delta^{13} \mathrm{C}_{\mathrm{C}}$ analysis, 1-mg samples of dry cellulose were transferred into tin capsules and measured at the Natural Environment Research Council (NERC) Isotope Geosciences Laboratory (British Geological Survey) by combustion in a furnace (Carlo Erba NA1500) connected to a dual-inlet Isotope-ratio mass spectrometer (VG Triple Trap and Optima). Sample ${ }^{13} \mathrm{C} /{ }^{12} \mathrm{C}$ isotope ratios were referenced to the Vienna Pee Dee belemnite scale using a laboratory standard calibrated against NBS-19 and NBS-22. Replicate analyses indicated a precision of $\pm<0.1 \%$ ( $1 \sigma)$.

For $\delta^{18} \mathrm{O}_{\mathrm{C}}$ analysis, 1-mg samples of dry cellulose were transferred into silver capsules and analysed at Godwin Laboratory, University of Cambridge using a Thermo Finnigan 253 stable isotope ratio mass spectrometer with a high temperature conversion elemental analyser (Thermo Fisher Scientific). Two laboratory standards, and an international standard, NBS 127 , were used to calibrate the reference gas. ISODAT software was used to calculate the sample values relative to this reference gas and anchor $\delta^{18} \mathrm{O}_{\mathrm{C}}$ to the VSMOW scale.

sodium hydroxide step with a final 1-h bleaching (14 g 
Fig. 2 a Mean monthly air temperatures recorded at AP meteorological stations (Scientific Committee on Antarctic Research 2014); b short-term temperature measurements at moss surface and non-protected air temperature above the moss at Elephant, Norsel and Green Island, compared with daily readings made on Signy Island in 2009-2010
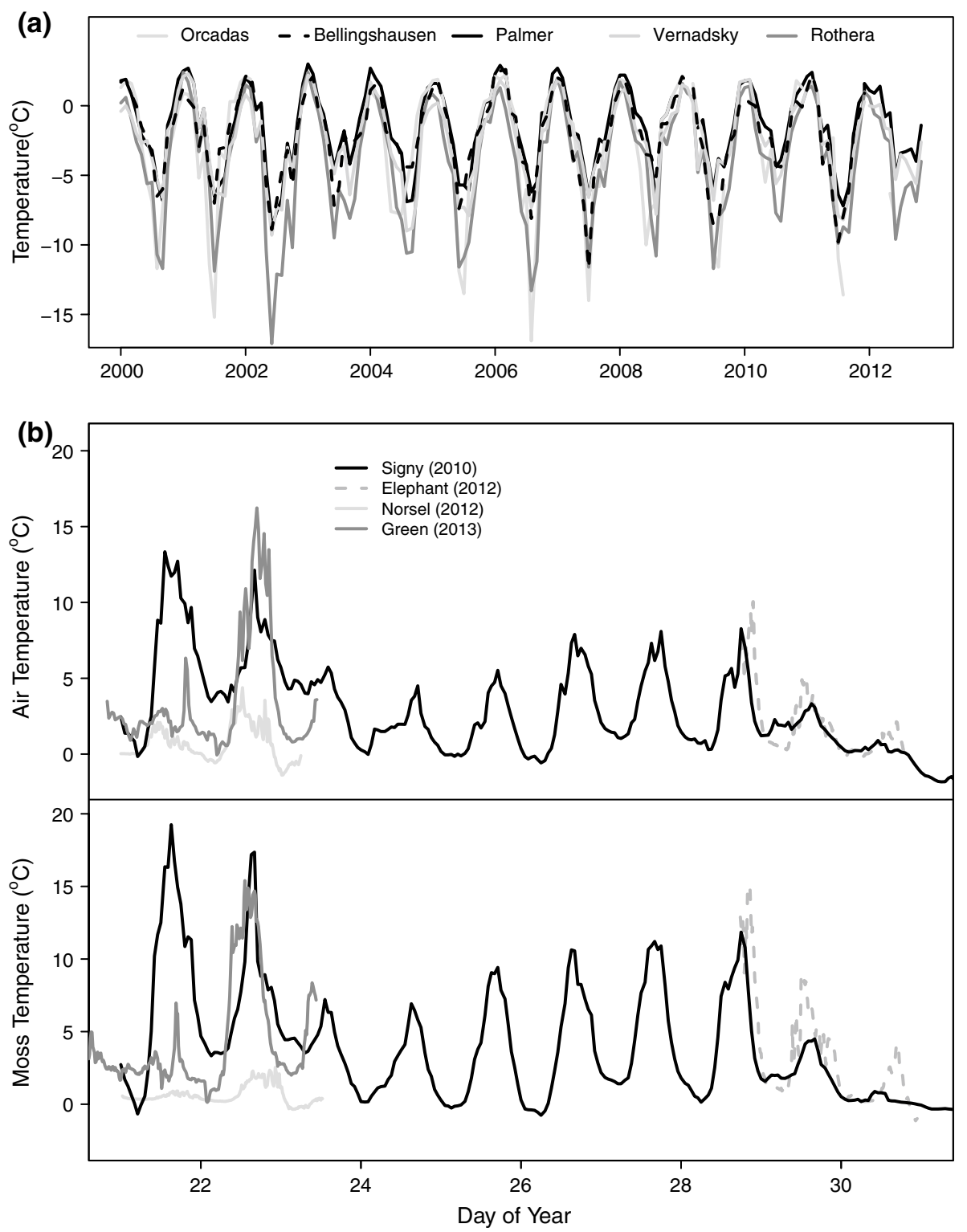

Statistical analyses were performed using $\mathrm{R}$ version 3.0.2 ( $\mathrm{R}$ Core Development Team 2014). To determine significant pairwise comparisons, normality of data was tested and either one-way ANOVA or Kruskal-Wallis rank sum tests applied, followed by post hoc Tukey tests or multiple comparison tests after Kruskal-Wallis [kruskalmc in the pgirmess package (Giraudoux 2014)] as appropriate.

\section{Testate amoebae populations}

To isolate testate amoebae, $2-\mathrm{cm}^{3}$ organic matter samples were prepared using standard techniques (Booth et al. 2010; Charman et al. 2000), with counts completed on the 300- to $15-\mu \mathrm{m}$ fraction. Concentration of tests per cubic centimetre was calculated from the addition of an exotic spore tablet [Lycopodium (Stockmarr 1971)] and converted to concentration of tests per dry gram using bulk density values (Table S1). Minimum counts of 100 tests per sample were sought but total counts of 50-99 $(n=21)$ and 25-49 $(n=10)$ were accepted. Although these totals are lower than generally recommended (Payne and Mitchell 2009), they provide robust concentration data and reasonable estimates of assemblage composition given the low overall taxonomic diversity. In two samples it was not possible to obtain a count $\geq 25$ and these were excluded.

Testate amoeba biomass estimates were calculated using standard techniques (Gilbert et al. 1998; Ju et al. 2014; Mitchell 2004; Payne et al. 2010), assuming geometric test shapes (Mitchell 2004), with dimensions applied based on microscopic measurements of shells (Table S4). Shell volumes were 
converted to $\mathrm{C}$ biomass using the factor $1 \mu \mathrm{m}^{3}=1.1 \times 10^{-7}$ $\mu \mathrm{g} \mathrm{C}$ (cf. Mitchell 2004; Weisse et al. 1990).

Shannon Wiener diversity index (SWDI) values (Sageman and Bina 1997) were calculated for each sample using the following equation:

SWDI $=-\sum_{i=1}^{S}\left(X_{i} / N_{i}\right) \times \ln \left(\frac{X_{i}}{N_{i}}\right)$

where $X_{i}$ is the abundance of each taxon, $N_{i}$ is the total abundance of the sample, and $S$ is the sample species richness. SWDI values of $0(n=5)$ were generated for monospecific samples.

Cluster analysis of testate amoeba data was completed using the cluster package (Maechler et al. 2014) in R version 3.0.2 (R Core Development Team 2014). An agglomerative hierarchical method was applied (function hclust) with a Bray-Curtis distance measure, Ward's linkage method and no standardisation of variables (cf. Swindles et al. 2009). Primary cluster groups (i.e. 1,2) were defined at a set level of similarity (distance $=1.5$ ), with subgroups (i.e. $2 \mathrm{~A}, 2 \mathrm{~B}$ ) assigned using the natural grouping of the dendrogram (Fig. S1). Cophenetic correlation, which calculates the correlation between the original distance matrix and the dendrogram, was used to assess the viability of the assigned clusters.

The relationship between the testate amoeba community (with proportions of taxa recorded as concentration of tests per dry gram) and environmental variables (latitude, moisture content, altitude and aspect) was investigated using canonical correspondence analysis (CCA) ordination in Canoco version 4.5 and CanoDraw version 4 (ter Braak and Šmilauer 2002). Euglypha rotunda, Euglypha tuberculata type, Hyalosphenia elegans and Hyalosphenia sp. were excluded as rare species. Vegetation data (Table S1) were included as passive variables, as host moss type can be inter-correlated with other environmental variables and may not assert direct control on the testate amoeba assemblage (cf. Swindles et al. 2009).

\section{Results}

\section{Contemporary measurements of climate and isotopic environment}

\section{Meteorological and microclimate conditions}

Mean monthly air temperatures recorded at Bellingshausen $\left(62^{\circ} 12^{\prime} \mathrm{S} 58^{\circ} 58^{\prime} \mathrm{W}\right.$, near ARD) and Vernadsky stations $\left(64^{\circ} 14^{\prime} \mathrm{S} 64^{\circ} 15^{\prime} \mathrm{W}\right.$, near GRE) between 2000 and 2012 fall in the range of $-9{ }^{\circ} \mathrm{C}$ to $+2{ }^{\circ} \mathrm{C}$, whilst annual temperatures remain below $0{ }^{\circ} \mathrm{C}$, but show warming trends (Figs. 1, 2; Scientific Committee on Antarctic Research 2014).
Microclimate data were recorded for only a few summer days, but moss surface and overhead air temperatures were tightly coupled, without temporal lag (Fig. 2b). Daily minimum temperatures were approximately $0{ }^{\circ} \mathrm{C}$, whilst the variation in daily maximum temperatures at a given site (e.g. approximately $10{ }^{\circ} \mathrm{C}$ range in maximum temperature measured at ELE) were similar to the range measured across the latitudinal gradient. The short-term measurements from ELE, NOR and GRE fit well with the longer term microclimate data recorded at Signy Island in 200910 (Fig. 2; Royles 2012). Moss temperatures were generally slightly warmer than air temperatures, but both reached maxima (ca. $15^{\circ} \mathrm{C}$ ) substantially higher than the mean monthly temperatures due to direct radiative processes.

\section{Species composition and physical characteristics of moss}

Moss samples comprised C. aciphyllum and P. strictum, the two known bank-forming species in this region (Table S1). Moisture content of the tissue at collection varied between 39 and $85 \%$, but the inter-quartile range (IQR) was narrow, $69-75 \%$ (Table S1). The bulk density ranged from 0.052 to $0.197 \mathrm{~g} \mathrm{~cm}^{-3}$, with an IQR of $0.09-0.12 \mathrm{~g} \mathrm{~cm}^{-3}$ (Table S1).

\section{Isotopic composition of contemporary source water}

The isotopic composition of AP precipitation, including all 57 rain and snow samples, was well explained by a highly significant local meteoric water line (LMWL; $\delta^{2} \mathrm{H}$ as a function of $\delta^{18} \mathrm{O}$ ) with a gradient of 7.3 , below that of the global meteoric water line (GMWL; $\delta^{2} \mathrm{H}=8 \delta^{18} \mathrm{O}+10$ ) across the measured range of $\delta^{18} \mathrm{O}$ values $(-2$ to $-16 \%$; Fig. 3). The AP LMWL lies above those from Rothera and Vernadsky/Faraday, the closest International Atomic Energy Agency (IAEA) Global Network of Isotopes in Precipitation (GNIP) stations, but is similar to LMWLs for Signy Island (Royles et al. 2013c) and O'Higgins station (Fernandoy et al. 2012), which were also derived from summer precipitation collections.

\section{Isotopic composition of moss water}

The moss water samples (Fig. 4) fell along a highly significant water line $\left(R^{2}=0.95, p<0.0001\right)$, with a similar range in $\delta^{18} \mathrm{O}$ values but a lower gradient (6.9) than the LMWL (7.3). The samples were generally geographically clustered, with samples from ARD and ELE (sub-site 1) at the relatively enriched end between 0 and $-5 \%$, the samples from GRE dominating the -5 to $-10 \%$ zone, and NOR samples more negative than $-12 \%$. A second cluster of samples from ELE (sub-sites 2 and 3 ) had $\delta^{18} \mathrm{O}$ values of approximately $-10 \%$. The moss water samples reflect a combination of cellular constituents and external interstitial 


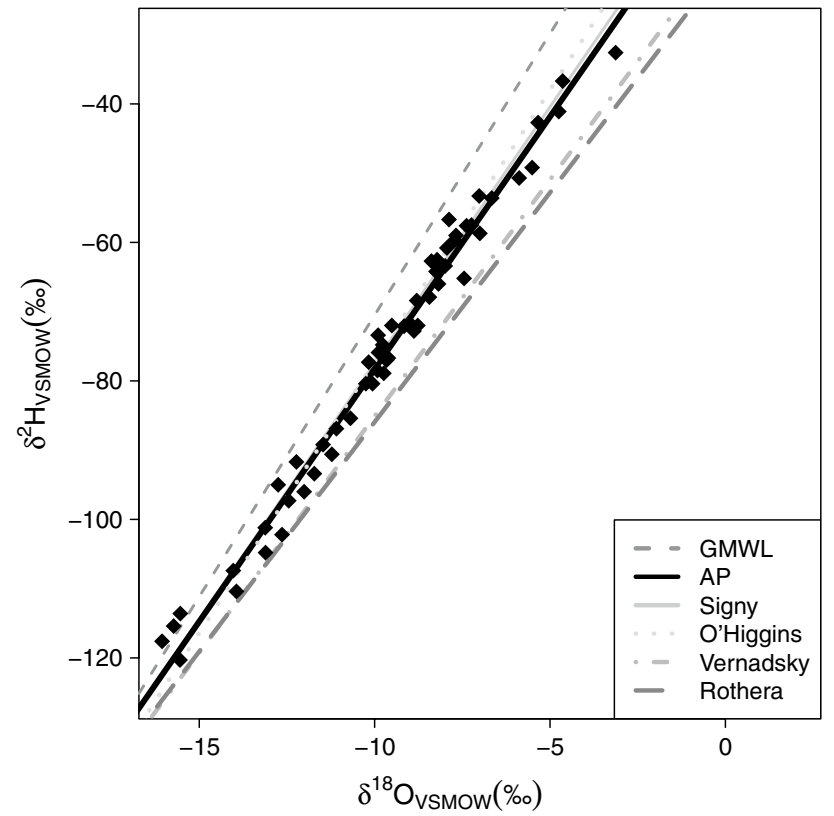

Fig. 3 AP local meteoric water line $(L M W L)$ generated from fieldwork samples (black diamonds and line), compared with LMWL from O'Higgins station (Fernandoy et al. 2012), Signy Island (Royles et al. 2013c), and International Atomic Energy Agency Global Network of Isotopes in Precipitation data from Vernadsky and Rothera. Highly significant linear model fitted to 57 water samples, equation of LMWL: $y=7.3 x-5.4, r^{2}=0.99, P<0.0001$. VSMOW Vienna Standard Mean Ocean Water

waters surrounding the living tissues, but fall strikingly close to the LMWL for Vernadsky, the local GNIP station (Fig. 4). In addition to recent precipitation inputs, other contributory factors would be winter snowmelt, the extent of thaw and freeze thaw cycles, and exchanges with atmospheric water vapour. The divergence from the LMWL in a subset of more enriched moss water samples from ELE and ARD is not considered to be significant in terms of evaporative recycling, but perhaps reflects repeated freeze-thawing cycles, as freezing affects $\delta^{18} \mathrm{O}$ and $\delta^{2} \mathrm{H}$ values differently, decreasing the slope of the MWL.

The moss water $\delta^{18} \mathrm{O}\left(\delta^{18} \mathrm{O}_{\mathrm{MW}}\right)$ values were significantly dependent upon latitude (Fig. 5a), although the range of values measured at each location (over $10 \%$ ) exceeded the $7 \%$ variation in the linear model fitted across the latitudinal range. The bimodal distribution of the ELE moss water $\delta^{18} \mathrm{O}$ values is in contrast with the continuous distributions of values from the other locations. Whilst a highly significant linear model can be fitted when the ELE site 2 and 3 samples are included [Fig. 5a (grey line); $p<0.0001$, $R^{2}=0.33$ ], substantially more variation is explained by the linear model when those points are excluded [Fig. 5a (black line); $\left.p<0.0001, R^{2}=0.67\right]$. At NOR and GRE mean $\delta^{18} \mathrm{O}_{\mathrm{SW}}$ fell in the middle of the range of $\delta^{18} \mathrm{O}_{\mathrm{MW}}$ values, at $\operatorname{ARD} \delta^{18} \mathrm{O}_{\mathrm{SW}}$ was at the depleted end of the $\delta^{18} \mathrm{O}_{\mathrm{MW}}$

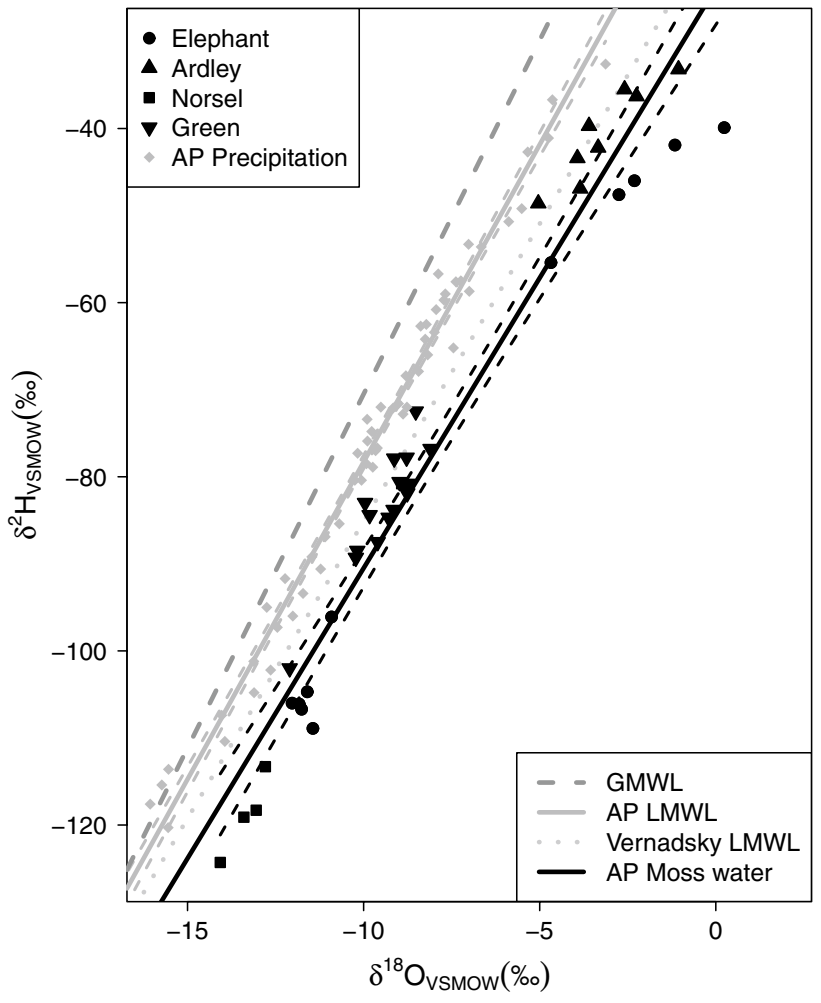

Fig. 4 Water lines $\left(\delta^{2} \mathrm{H}\right.$ vs. $\left.\delta^{18} \mathrm{O}\right)$ for AP source water samples (light grey $\left.y=7.3 x-5.4, r^{2}=0.99, n=57, P<0.0001\right)$ and moss water samples (black $y=6.7 x-23.8, r^{2}=0.95, P<0.0001$ ) in which water was distilled from surface moss samples. Long dashed line represents the global meteoric water line $(G M W L ; y=8 x-10)$, dotted line is Vernadsky LMWL. Dashed lines represent $95 \%$ confidence intervals of linear models

values, whilst at ELE, $\delta^{18} \mathrm{O}_{\mathrm{SW}}$ was around $-12 \%$, similar to that of the moss water from ELE sites 2 and 3, and around $10 \%$ more depleted than that of the ELE site 1 moss water. There was no significant relationship between $\delta^{18} \mathrm{O}_{\mathrm{MW}}$ and $\delta^{18} \mathrm{O}_{\mathrm{C}}$ from associated moss tissue within or between locations. The enrichment factor between cellulose and moss water ranges $26-42 \%$ and increases with latitude (Fig. 5b), though again the ELE sites demonstrate a bimodal distribution, driven by the more negative $\delta^{18} \mathrm{O}_{\mathrm{MW}}$ samples from ELE 2 and 3.

\section{Measurements of modern proxy analogues}

\section{Isotopic composition of cellulose}

With a mean $3 \%$ offset between species, $\delta^{13} \mathrm{C}_{\mathrm{C}} P$. strictum was significantly more negative than $\delta^{13} \mathrm{C}_{\mathrm{C}}$ C. aciphyllum (Fig. 6a). Along with species, the moisture content of the moss tissue was a significant explanatory factor of the ${ }^{13} \mathrm{C}_{\mathrm{C}}$ values, with less negative $\delta^{13} \mathrm{C}_{\mathrm{C}}$ values associated with wetter tissue (ANOVA, species, $F=85.6$, mean square error $=100.54, P<0.01$; moisture content, $F=7.56$, mean 

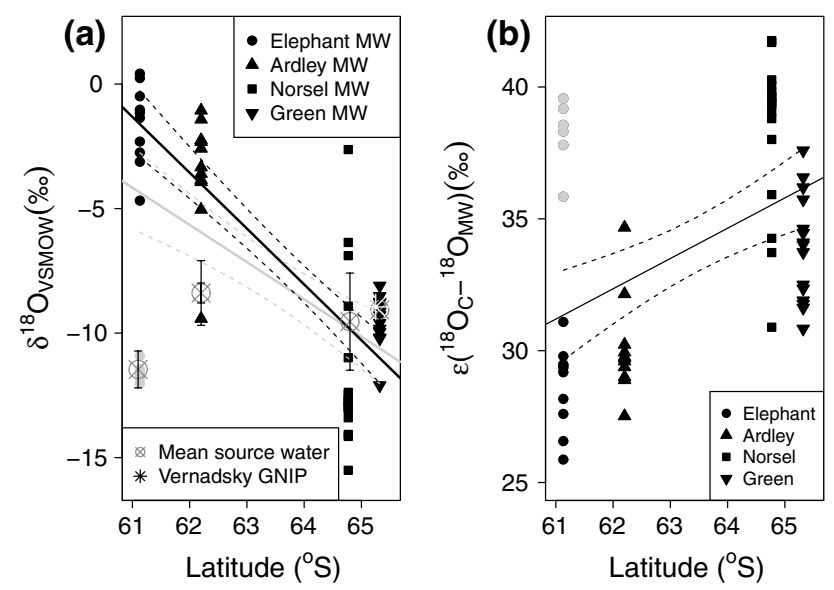

Fig. 5 a $\delta^{18} \mathrm{O}$ composition of moss water $(M W)$ as a function of latitude. Dots Elephant Island (ELE; light grey dots represent data from ELE sites 2 and 3), upward triangles Ardley Island (ARD), squares Norsel Point (NOR), downward triangles Green Island (GRE). Grey line significant linear model fitted to all data, plotted with $95 \%$ confidence interval; black line significant linear model fitted to black data points (excluding ELE sites 2,3) plotted with $95 \%$ confidence interval. Grey cross-hairs represent mean $\delta^{18} \mathrm{O}$ composition of source water (error bars represent SE), white asterisk indicates January precipitation at Vernadsky. b Enrichment of $\delta^{18} \mathrm{O}_{\mathrm{C}}$ relative to $\delta^{18} \mathrm{O}_{\text {moss- }}$ water as a function of latitude. Black line significant linear model fitted to all data $\left(P=0.0011, r^{2}=0.14\right)$ and plotted with $95 \%$ confidence interval. Light-grey dots represent data from ELE sites 2 and 3

square error $=8.87, P<0.01)$. The $\delta^{18} \mathrm{O}$ composition of $C$. aciphyllum was significantly more enriched than that of $P$. strictum (Fig. 6b). The mixed species samples had isotopic compositions intermediate between the monospecific samples.

The $\delta^{13} \mathrm{C}_{\mathrm{C}}$ values of ELE C. aciphyllum samples were significantly more negative than the NOR samples, but the other sites were indistinguishable (Fig. 6c) and there were no significant inter-site differences in P. strictum $\delta^{13} \mathrm{C}_{\mathrm{C}}$ values (Fig. 6e). Whilst there were no significant differences in C. aciphyllum ${ }^{18} \mathrm{O}_{\mathrm{C}}$ values between the islands, the single sample from GRE was $5 \%$ more depleted than the very consistent values of $27 \%$ measured from ELE, ARD and NOR (Fig. 6d). For P. strictum, the most southerly analysed samples, those from GRE were significantly more depleted than those from NOR and ELE (Fig. 6f).

\section{Testate amoebae assemblages}

The testate amoebae assemblages had very low diversity (Fig. 7), with only 13 taxa identified, and eight of those occurring in fewer than ten samples with a maximum abundance $<10 \%$ (Table S3). Corythion dubium type was very widespread, occurring in $95 \%$ of samples, the dominant taxon in $63 \%$ of samples and highly morphologically variable with a mean length of $41 \mu \mathrm{m}$ (range $=27-57 \mu \mathrm{m}, 1 \sigma=7 \mu \mathrm{m}$ ) and width of $27 \mu \mathrm{m}$ (range $=17-38 \mu \mathrm{m}, 1 \sigma=5 \mu \mathrm{m}) . C$. dubium was previously classified into size fractions (Royles et al. 2013a) but here we treat it as one class, until any systematic morphological and genetic differences that exist within the morphotype are determined (e.g. Bobrov et al. 1999; Oliverio et al. 2014). Microcorycia radiata type was identified in the Antarctic region for the first time (Meisterfeld, unpublished database), and occurred in $67 \%$ of samples, whilst Assulina muscorum also occurred frequently (61\% of samples) but was less dominant than either $C$. dubium or $M$. radiata types (Table S3). Unknown type occurred in only seven samples (12\%), but was the dominant taxon in one ARD sample.

Mean sample concentrations (27,830 tests dry $\mathrm{g}^{-1}$; Tables 1; S3) were less than half those reported from an Alaskan Arctic fen (Mitchell 2004), but had double the SD. Mean sample biomass (49.8 $\mu \mathrm{g} \mathrm{C} \mathrm{g}^{-1}$; Tables 1 , S3) was considerably lower than that reported by Mitchell (2004), reflecting the dominance of small taxa. Regressions of biomass estimates against mean microclimate temperature (not shown) resulted in no significant correlations. Cluster analysis divided the testate amoebae dataset into four primary groups either dominated by $M$. radiata type (group 1 ) or $C$. dubium type (group 2), containing primarily a mixture of the two (group 4), or a more diverse assemblage (group 3; Fig. S1). A high cophenetic correlation (0.768) suggested that these clusters were a reliable representation of the original dataset. CCA axes 1 (eigenvalue 0.306) and 2 (eigenvalue 0.066 ) together explained $26.8 \%$ of the variability in the testate amoeba data and $98 \%$ of the species-environment relationship (Fig. 8; Table S5). Latitude and altitude were the environmental variables most strongly related to axis 1 , with the two main moss taxa, $C$. aciphyllum and $P$. strictum, positioned at opposite ends of the axis reflecting the broad geographic pattern observed in the distribution of the two bank-forming species. Axis 2 was principally related to moss moisture content, which is an important determinant of testate amoeba assemblages in temperate peatlands (e.g. Amesbury et al. 2013; Swindles et al. 2009). However, our data do not support this explicit hydrological link. In line with the broadly cosmopolitan testate amoeba assemblage, most taxa clustered in the centre of the ordination space without clear alignment along either of the principle axes of variability. This was especially true of the dominant taxon $C$. dubium type, which fell almost at the 0 , 0 intercept.

\section{Discussion}

\section{Contemporary growth environment}

Mean annual temperatures on the AP are sub-optimal for C. aciphyllum and P. strictum (Davey and Rothery 1997); however, moss surface temperatures are often substantially 
Fig. 6 Stable isotope composition of cellulose for surface moss samples of bank-forming species (number of sites included); different letters denote significantly different groups. a $\delta^{13} \mathrm{C}$ and $\mathbf{b} \delta^{18} \mathrm{O}$ composition of all Chorisodontium aciphyllum, Polytrichum strictum and mixed samples (C. aciphyllum/P. strictum); c $\delta^{13} \mathrm{C}$ and $\mathbf{d} \delta^{18} \mathrm{O}$ composition of pure $C$. aciphyllum samples, divided by island; $\mathbf{e} \delta^{13} \mathrm{C}$ and f $\delta^{18} \mathrm{O}$ composition of pure $P$. strictum samples, divided by island. Boxes represent interquartile range (IQR) of data, whiskers extend to a maximum of 1.5 IQR. For other abbreviations, see Fig. 5
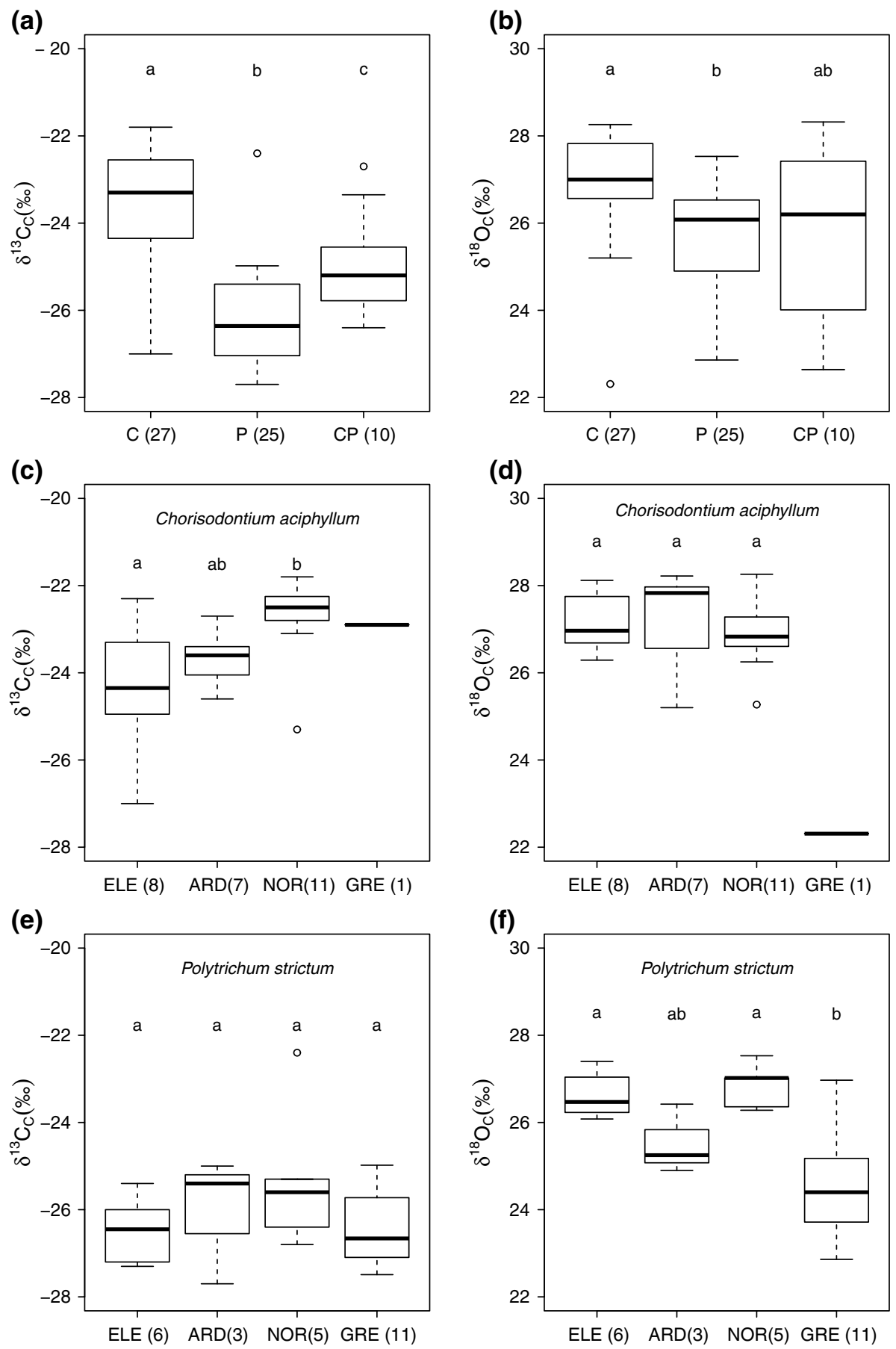

warmer than air temperatures (Fig. 2b) (e.g. Bramley-Alves et al. 2014; Smith 1988), with diurnal variation exceeding the latitudinal AP temperature cline. As temperature sensitivity responses are generally shallow, despite the sub-optimal air temperature, AP mosses can regularly photosynthesise at a high proportion of their maximal rate (Convey 1996; Longton 1988). As shown by the species compositions reported here, whilst $P$. strictum and $C$. aciphyllum are both found across the AP, $C$. aciphyllum is the dominant bank-forming species at northern sites, and $P$. strictum dominates the drier, southerly sites (Fenton and Smith 1982).

\section{Relationship between isotopic composition of source water and moss tissue water}

The AP LMWL was almost identical to the Signy Island (Royles et al. 2013c) and O'Higgins station LMWLs (Fernandoy et al. 2012), which are located to the north-east and east of our sampling sites, respectively (Figs. 1, 3). Water 


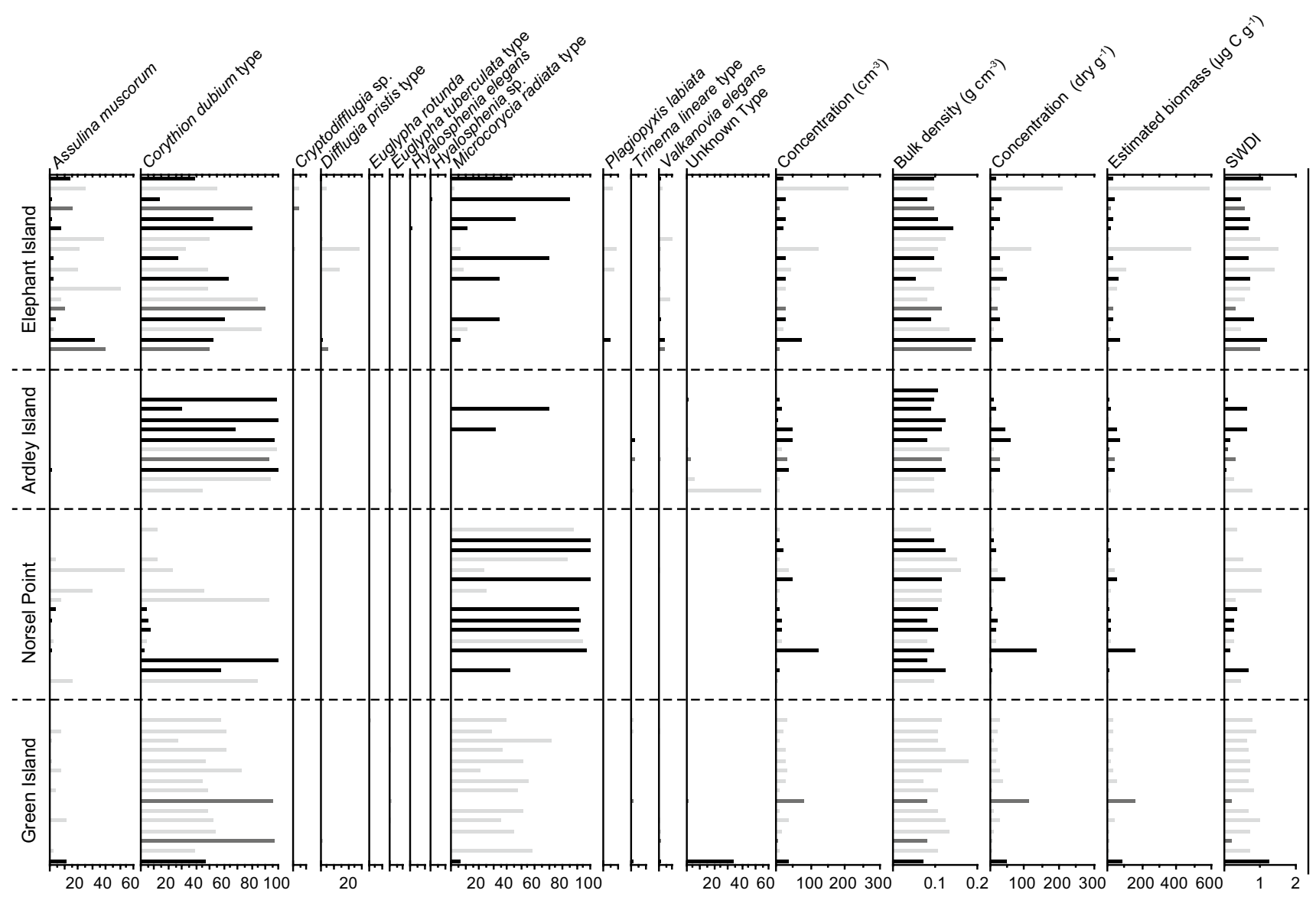

Fig. 7 Testate amoebae distribution and abundance, sub-divided by site (Table 1) and colour coded by moss type (light grey P. strictum, black C. aciphyllum, mid-grey C. aciphyllum-P. strictum mix) (see "Testate amoebae populations" for details). SWDI Shannon Wiener diversity index

Table 1 Summary testate amoeba data by site

\begin{tabular}{|c|c|c|c|c|c|c|}
\hline \multirow[t]{2}{*}{ Site } & \multicolumn{2}{|c|}{ Concentration (tests dry $\mathrm{g}^{-1}$ ) } & \multicolumn{2}{|c|}{ Biomass $\left(\mu \mathrm{g} \mathrm{C}^{-1}\right)$} & \multicolumn{2}{|l|}{ SWDI } \\
\hline & Mean $\pm 1 \mathrm{SD}$ & Median & Mean $\pm 1 \mathrm{SD}$ & Median & Mean $\pm 1 \mathrm{SD}$ & Median \\
\hline Signy $^{\mathrm{a}}$ & $157,634 \pm 254,898$ & 73,404 & $912 \pm 1943$ & 121 & $1.18 \pm 0.50$ & 1.14 \\
\hline Elephant Island & $38,521 \pm 50,436$ & 26,010 & $92 \pm 164$ & 34 & $0.86 \pm 0.35$ & 0.75 \\
\hline Ardley Island & $19,897 \pm 18,119$ & 10,114 & $27 \pm 23$ & 13 & $0.30 \pm 0.28$ & 0.28 \\
\hline Norsel Point & $21,001 \pm 32,368$ & 13,920 & $27 \pm 39$ & 21 & $0.36 \pm 0.34$ & 0.18 \\
\hline Green Island & $26,253 \pm 26,426$ & 20,991 & $35 \pm 39$ & 28 & $0.73 \pm 0.26$ & 0.74 \\
\hline Lazarev Bay ${ }^{\mathrm{b}}$ & 16,630 & - & 21.48 & - & 0.04 & - \\
\hline All sites & $27,831 \pm 35,907$ & 16,935 & $49.8 \pm 97.9$ & 21 & $0.59 \pm 0.39$ & 0.64 \\
\hline
\end{tabular}

SWDI Shannon-Wiener diversity index

a Unpublished data from Signy Island, South Orkney Islands

b Lazarev Bay, Alexander Island (Royles et al. 2013a); one data point included based on top $3.2 \mathrm{~cm}$ of core for which bulk density values were available to calculate concentration (tests dry $\mathrm{g}^{-1}$ ) samples were collected close to sea level, on windy, oceanic islands, so altitude or rain-out effects were minimal, as shown by the consistency of the LMWL across the sample transect. The moss water line is distinct from the LMWL (Fig. 4). The moss water is likely to represent water integrated over a longer time period than the precipitation samples, which contain water from a single precipitation event. Analysis of the GRE water samples shows this temporal integration and mixing of precipitation into the moss water. Whilst the GRE LMWL lies above the Faraday/ Vernadsky LMWL, the GRE moss water line is very similar to the Faraday/Vernadsky LMWL (Fig. 4). In addition, 


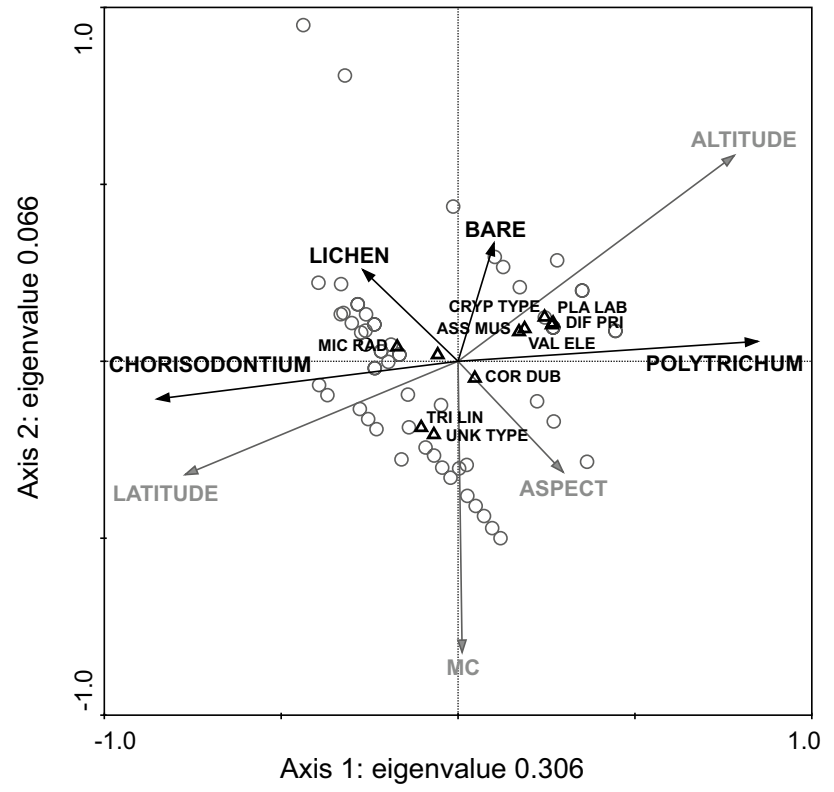

Fig. 8 Results of canonical correspondence analysis showing environmental variables (grey), passive environmental variables (i.e. vegetation types; black), taxa (triangles; labelled) and samples (grey circles). MC Moisture content

the range of $\delta^{18} \mathrm{O}$ values contributing to the LMWL (6\%) exceeded that of the moss water $(2 \%)$. The mean monthly $\delta^{18} \mathrm{O}$ values of summer (December-March) precipitation measured at Vernadsky fall between -8.5 and $-9 \%$ [IAEA and World Meteorological Organization (WMO) 2014] compared to moss water $\delta^{18} \mathrm{O}$ values of -8 to $-10 \%$. Thus, in line with hypothesis 1 , the isotopic composition of moss water provides a good approximation of summer precipitation composition, better than that obtained from spot collections of precipitation. Furthermore, the moss water oxygen isotope composition partially reflected the well-recognised latitudinal effect on the isotopic composition of precipitation (Dansgaard 1964; Gat 1998) (Fig. 5a); however, there was not a significant relationship between $\delta^{18} \mathrm{O}_{\mathrm{SW}}$ and latitude. Sampling in remote AP locations was necessarily spatially and temporally limited, potentially confounding comparisons between locations. However, the linearity of the AP LMWL and moss water line, the samples not being collected in latitudinal order and the overlap in temperature measurements made across the transect give confidence to our cross-transect comparisons.

The approximate $10 \%$ separation at ELE between $\delta^{18} \mathrm{O}_{\mathrm{MW}}$ values from sub-site 1 compared to sub-sites 2 and 3 is clear. The sites are within $1 \mathrm{~km}$ of each other, so the timing and isotopic composition of precipitation should be consistent. One explanation is that the very exposed subsite 1 , from a 3 -m-deep moss bank, is solely fed by relatively isotopically enriched summer rain, as the slope and aspect of the bank are unable to support winter snow banks.
In contrast, the banks at sub-sites 2 and 3 have lower profiles above the ground surface and shallower inclines and thus may have incorporated more isotopically depleted snowmelt water, either from snow settling on the moss, or run-off from surrounding areas. Indeed, the two most isotopically enriched samples from ELE fell below the moss water line (Fig. 4), possibly indicating humiditydependent secondary evaporative effects on LMWL source waters. However, the cool, windy AP conditions with frequent precipitation are generally unfavourable for multiple evaporative recycling events. The relative humidity/vapour pressure at the moss surface is generally high, with a low vapour pressure gradient to the atmosphere, and the low air temperatures reduce evaporative demand. Net evaporation of water from the moss surface is likely to be low, but there may be exchange between moss water and water vapour, with the isotopic composition of the vapour being imprinted onto the moss water and, potentially, cellulose (Ellwood et al. 2011; Helliker and Griffiths 2007).

\section{Cellulose $\delta^{18} \mathrm{O}$ and $\delta^{13} \mathrm{C}$ as palaeoenvironmental proxies on the AP}

Across all sites the moss was growing in exposed, windy locations, without canopy cover and with minimal local sources of respiratory $\mathrm{CO}_{2}$. Consequently, we assume that all the mosses were assimilating atmospheric $\mathrm{CO}_{2}$, with the associated contemporary $\delta^{13} \mathrm{C}$ signature of approximately $-8 \%$ o (Keeling et al. 2008; Rubino et al. 2013). Radiocarbon dating techniques show that $C$. aciphyllum on Signy Island $\left(60^{\circ} 45^{\prime} \mathrm{S}\right)$ has recently accumulated at up to $3.9 \mathrm{~mm} \mathrm{year}^{-1}$ (Royles et al. 2012) whilst P. strictum on Alexander Island $\left(69^{\circ} 22^{\prime} \mathrm{S}\right)$ has been accumulating at approximately $4 \mathrm{~mm}$ year $^{-1}$ (Royles et al. 2013a). Consequently it is expected that the surface moss samples, with green growing tips of approximately $5 \mathrm{~mm}$, represent a similar growth period at all locations, despite the difference in latitude and species (Royles and Griffiths 2014).

The $\delta^{13} \mathrm{C}_{\mathrm{C}}$ values are significantly more negative in $P$. strictum than in $C$. aciphyllum and, furthermore, are significantly more negative in moss samples with a lower moisture content, due to variation in the biochemical fractionation and/or diffusion resistance to $\mathrm{CO}_{2}$ (Farquhar et al. 1989). Polytrichales (including P. strictum) have surface lamellae which facilitate $\mathrm{CO}_{2}$ diffusion (Proctor 2005) and enable the maintenance of high rates of photosynthesis when other mosses would become either $\mathrm{CO}_{2}$ limited due to the covering water film or desiccated. Thus, for mosses with the same external water layer, the rate of $\mathrm{CO}_{2}$ diffusion will be higher in P. strictum than $C$. aciphyllum, facilitating greater fractionation against ${ }^{13} \mathrm{CO}_{2}$ (Rice and Giles 1996). In addition, a higher proportion of the seasonal net assimilation will occur under high discrimination 
conditions, which is reflected in a more negative seasonally integrated $\delta^{13} \mathrm{C}_{\mathrm{C}}$ value (Royles et al. 2012).

Between locations, for the same species, the extent of the external water layer (and consequently fractionation) is influenced by wetness and wind. The $\delta^{13} \mathrm{C}_{\mathrm{C}}$ data for $C$. aciphyllum suggest that the conditions at the photosynthetic apices of the moss are either windier or drier at ELE than at NOR (or a combination of the two). A similar depletion was measured between the $P$. strictum samples, but with fewer samples the difference was not statistically significant. Meteorological information from ELE is very limited but, between December 1970 and March 1971, the mean wind speed was $26 \mathrm{~km} \mathrm{~h}^{-1}$ (O'Brien 1974) whilst at Palmer station (close to NOR) the mean was $19.5 \mathrm{~km} \mathrm{~h}^{-1}$ (LTER 2014). Whilst these measurements are not comparable in time period, the isolated location of ELE, exposed to the westerly winds at the boundary between Drake Passage and Weddell Sea, and the high altitude of the moss banks (ca. $200 \mathrm{~m}$ a.s.l. compared to $20 \mathrm{~m}$ a.s.l. at NOR), suggest that higher winds may be a feasible and important factor in determining the microclimate conditions at the moss surface. Thus there is partial support for hypothesis 2 , that $\delta^{13} \mathrm{C}_{\mathrm{C}}$ is a record of photosynthetic conditions, but any strong latitudinal dependence is overridden by local growing season conditions.

The latitudinal gradient in $\delta^{18} \mathrm{O}_{\mathrm{C}}$ was significant when all the samples were pooled, providing further support for hypothesis 1 (that moss water and cellulose $\delta^{18} \mathrm{O}$ values are markers of precipitation composition), but substantial variation remains to be explained. $\delta^{18} \mathrm{O}_{\mathrm{C}}$ is not a direct reflection of the isotopic composition of precipitation due to evaporative enrichment, water vapour isotopic exchange, and fractionation during synthesis of isotopic exchange between water and organic molecules, and the temporal offset between precipitation and cellulose synthesis. However, the enrichment factor between cellulose and moss water was greater than the $27 \pm 3 \%$ o biochemical fractionation factor (Barbour 2007; but see Sternberg and Ellsworth (2011), suggesting that evaporative enrichment occurred in the moss tissue prior to cellulose synthesis. The majority of moss cellulose synthesis takes place within the small, photosynthetic leaf tips, so the evaporative enrichment of the leaf water can be imprinted onto the primary assimilate and subsequently the cellulose. The small volume of water within the photosynthetic moss apices is in contrast to the larger volume of water associated with the non-photosynthetic tissues that comprised the majority of the 50-mm-deep moss samples, and the moss tissue water analysed here. Being lower in volume, and more exposed to wind, the isotopic composition of the water within the apices will change more rapidly and likely undergo more evaporative enrichment than the external tissue water, potentially explaining the lack of tight isotopic coupling between the external water and the cellulose.
Testate amoebae as palaeoenvironmental proxies on the AP

The dominance of small, cosmopolitan taxa within low diversity, low-concentration testate amoeba assemblages is consistent with previous research in AP (Mieczan and Adamczuk 2014; Smith and Wilkinson 2007; Wilkinson 2001; Yang et al. 2010), Arctic (Beyens et al. 1986, 1990, 1992) and sub-Antarctic (Vincke et al. 2004, 2006) peatlands as well as in Polytrichum spp.-dominated temperate peatlands (Mieczan 2009; Mitchell and Gilbert 2004). $M$. radiata type is reported here for the first time from the Antarctic region (Meisterfeld, unpublished data), but its frequent occurrence suggests it is an integral part of the regional fauna that may have been previously overlooked. With the exception of NOR samples dominated by $M$. radiata type (Fig. S1, group 1), the mixed distribution of sites throughout the clusters suggests that living conditions for testate amoeba are relatively homogeneous along the site transect, which is supported by microclimatic data (Fig. S1).

The three indicators of testate amoebae productivity (concentration, estimated biomass and species diversity) tended to covary between sites, with larger populations having higher biomass and diversity. ELE, the northernmost site, had the highest productivity values, suggesting some degree of latitudinal temperature dependence of testate populations, which is supported by the CCA results where latitude was aligned with the primary axis of variability (Fig. 8) and the previously defined latitudinal 'depauperization' of Antarctic and sub-Antarctic testate amoeba fauna (Smith 1996). However, GRE had higher concentration, estimated biomass and species diversity than either ARD or NOR, suggesting that any such effect is not straightforward (Table S5). Only when AP productivity data from Signy Island (South Shetland Islands; unpublished) and Lazarev Bay (Alexander Island; Royles et al. 2013a) are included does evidence for gradients in testate productivity indicators become more convincing (Table 1). The similarity of recent summer temperature records from Orcadas (near Signy) north of Rothera (near Lazarev) in the south, alongside the general mixing of sites in the cluster analysis (Fig. S1) suggests that other variables must be driving differences in productivity (Mieczan and Adamczuk 2014; Smith 1996). However, rapid increases in AP testate amoebae concentration over the last 50 years have been linked to the regional warming trend (Royles et al., 2013a), which is plausible because the ca. $3{ }^{\circ} \mathrm{C}$ temperature change is far greater than the spatial differences in contemporary climate (Figs. 1, 2). Relatively little research has been undertaken into the long-term effects of warming on testate amoebae populations. In situ [2 years (Jassey et al. 2013)] and growth chamber [8 weeks (Jassey et al. 2013)] experiments 
demonstrated significant effects of temperature on testate amoebae community structure, but with opposing positive and negative effects on abundance and biomass. In a Subarctic Sphagnum peatland, summer warming was associated with decreased species richness and community compositional shift towards xerophilous taxa (Tsyganov et al. 2012). On the AP, the recent warming trend has been associated with increased moisture availability and therefore an increase in xerophilous taxa is unlikely in this context. Moisture content was only weakly correlated to CCA axis 2 (Fig. 8), meaning that the limited variability measured across the transect may have been insufficient to drive observable change, although the generally high moisture contents mean that dryness is unlikely to drive the observed low concentrations and diversity (cf. Mieczan and Adamczuk 2014).

The relative homogeneity of testate amoeba community structure and associated environmental data over the 600$\mathrm{km}$ gradient of sites in this study mean that uncertainty remains as to the key drivers of assemblage changes over space and time, meaning that hypothesis 3 can be neither fully accepted nor rejected. Enigmatic variations remain in the dataset, such as the lack of $A$. muscorum at ARD and the much reduced concentrations of $C$. dubium and $M$. radiata type at NOR and ELE/ARD respectively. Whilst these features could result from stochastic variability relating to biogeographical factors (e.g. Yang et al. 2010), the cosmopolitan nature of the taxa involved makes this unlikely and suggests that there are relationships between testate amoebae and their (micro-)environmental setting that remain to be determined.

\section{Regional versus local factors in driving contemporary AP moss ecosystems}

Meteorological observations, along with model outputs of future climate and species distribution, are generated over spatial scales orders of magnitudes larger than individual organisms (Potter et al. 2013). In contrast, for all organisms, and especially for largely sessile microbes and plants, it is the local microclimate conditions which are critical to determining the timing and extent of metabolic activity. For example, whether moss is growing in sun or shade, or within a small cushion or a large moss bank, determines the leaf temperature. Subsequently leaf temperature, largely through enzyme activity, affects net assimilation and testate amoebae division rates, and, consequently, determines the dynamics for organic matter synthesis and microbial population development.

Similarly, there are local impacts that can decouple the isotopic composition of leaf water from the annual average precipitation input. Specifically, the extent of isotopic evaporative enrichment is dependent on the microclimatic sunshine, wind speed and wetness, all individually functions of moss surface microtopography (Lucieer et al. 2013; Ménot-Combes et al. 2002) and the water turnover time. AP summers are wet so, as the high moisture contents of the moss samples suggest, desiccation of moss tissue is rare, particularly over the 5-cm depth sampled here. However, the photosynthetically active upper $5 \mathrm{~mm}$ green tips are likely to go through substantially more wetting-drying cycles than the denser, more protected, non-photosynthetic tissue below. The moss water volume will be filled following the influx of precipitation or melt water, whilst available free water is potentially lost to evaporation, percolation, drainage and freezing. Consequently the moss water represents a weighted average of the inputs minus the outputs integrated between freezing events, rather than just reflecting the most recent wetting event.

Moisture content also has a significant influence on the extent of ${ }^{13} \mathrm{C}$ discrimination, with mosses in wet patches in the bottom of hollows, or growing in flushes, having long metabolically active periods, but, coupled with restricted $\mathrm{CO}_{2}$ diffusion, limited discrimination against ${ }^{13} \mathrm{CO}_{2}$ throughout the growing season. Moss shoots growing on the microtopographical peaks experience windier conditions (Wasley et al. 2012), dry out quickly and thus have a short active period, but spend a higher proportion of that active time with little $\mathrm{CO}_{2}$ diffusion limitation than those growing in wet flushes. Consequently, as the data here suggest, the drier mosses discriminate more against ${ }^{13} \mathrm{CO}_{2}$ and will have organic matter relatively depleted in ${ }^{13} \mathrm{C}$, and this sensitivity is important for the use of these species as palaeoclimate proxies (Bramley-Alves et al. 2015). The surface topography is unlikely to have changed over the course of growth of the contemporary samples and, thus, with climate, species and $\mathrm{CO}_{2}$ inputs equal the measured ${ }^{13} \mathrm{C}$ values should provide a good reflection of current microtopographical conditions. However, on translation into the palaeo-context this scenario has important implications. Depending upon the relative accumulation rates of mosses in peaks and hollows over time, a surface point could have switched microtopographical position affecting the isotope discrimination measurements within a peat core. There is thus a need for comparison of multiple records from separate locations so that consistency between records can be used to test whether changes have been driven by climate or local change.

\section{Interpretation of contemporary proxy measurements}

Even amongst contemporary ecosystems in an environment with strong physical drivers and little biotic competition, the responses of biological systems are not directly coupled to average climate or instantaneous physical inputs. Rather, they are strongly influenced by microclimate, as the time 
periods for metabolic activity are limited and generally have non-linear responses to temperature. This dependence on microclimate of all the measured proxies has both benefits and problems for interpreting palaeoclimate archives. Proxy records will rarely be directly interpretable in terms of climate variations recorded at a meteorological station. However, when consistent variations between locations are observed, they are likely to be due to a wide scale climatic signal, whilst perturbations recorded at only one or a subset of sites will most likely reflect local effects. In addition, depending upon the resolution of analysis, preserved material provides a temporally integrated signal over periods of a single season to decades. Surface moss tissue water can be analysed to provide an estimate of the annual average precipitation composition in regions without regular monitoring. The isotopic composition of cellulose is a weighted average from the growing season, whilst the testate amoebae population represents the microbial biomass present throughout the moss growth interval, which may encompass several generations within one annual cycle.

\section{Can moss isotope values and testate amoebae be used as palaeoclimate proxies on the AP?}

Substantial temporal variation in $\delta^{13} \mathrm{C}_{\mathrm{C}}$ values (Royles et al. 2012, 2013a) and testate amoeba populations (Royles et al. 2013a) have been measured in moss cores from the AP and continental Antarctica (Bramley-Alves et al. 2014; Clarke et al. 2012), whilst $\delta^{18} \mathrm{O}$ and testate amoeba variations over time are recorded in moss-based contexts from around the world. The relative consistency of contemporary measurements of potential proxies shown here means that where temporal variations are determined in future, down-core proxy measurements that cover hundreds or thousands of years we can conclude that the environmental conditions in which they were generated were beyond the range of conditions currently found across our transect of the AP.

Acknowledgments The research was funded by the NERC Antarctic Funding Initiative Grant NE/H014896/ to D. J. C., P. C., D. A. H. and H. G.; P. C., D. A. H. and J. R. contribute to the BAS Polar Science for Planet Earth research programme. Carbon isotope analyses were undertaken by Chris Kendrick at the NERC Isotope Geosciences Laboratory. Sample collection was supported by HMS Protector and HMS Endurance. Thanks to Iain Rudkin and Ashly Fusiarski for fieldwork support, to Adrian Dahood for water sample collection and to Sue Rouillard in the University of Exeter Geography drawing office for Fig. 1.

Author contribution statement $\quad$ D. J. C., P. C., H. G. and D. A. H. initially conceived the study and applied for funding; the fieldwork was completed by M. J. A., D. J. C., P. C., D. A. H. and J. R.; the laboratory work was completed by M. J. A., G. D. J., T. P. R. and J. R.; the data analysis was completed by M. J. A., J. R. and T. P. R.; J. R., M. J. A. and T. P. R. drafted the manuscript and all authors provided editorial advice and contributed to subsequent revisions.
Open Access This article is distributed under the terms of the Creative Commons Attribution 4.0 International License (http://creativecommons.org/licenses/by/4.0/), which permits unrestricted use, distribution, and reproduction in any medium, provided you give appropriate credit to the original author(s) and the source, provide a link to the Creative Commons license, and indicate if changes were made.

\section{References}

Amesbury MJ et al (2013) Statistical testing of a new testate amoebabased transfer function for water-table depth reconstruction on ombrotrophic peatlands in north-eastern Canada and Maine, United States. J Quat Sci 28:27-39. doi:10.1002/jqs.2584

Arigony-Neto J et al (2009) Spatial and temporal changes in drysnow line altitude on the Antarctic Peninsula. Clim Change 94:19-33

Barbour MM (2007) Stable oxygen isotope composition of plant tissue: a review. Funct Plant Biol 34:83-94

Barrand NE et al (2013) Trends in Antarctic Peninsula surface melting conditions from observations and regional climate modeling. J Geophys Res Earth Surf. doi:10.1029/2012jf002559

Beyens L, Chardez D, De Landtsheer R, De Bock P, Jacques E (1986) Testate amoebae populations from moss and lichen habitats in the Arctic. Polar Biol 5:165-173

Beyens L, Chardez D, De Baere D, De Bock P, Jaques E (1990) Ecology of terrestrial testate amoebae assemblages from coastal Lowlands on Devon Island (NWT, Canadian Arctic). Polar Biol 10:431-440

Beyens L, Chardez D, De Baere D, De Bock P (1992) The testate amoebae from the Søndre Strømfjord Region (West-Greenland) their biogeographic implications. Arch Protistenk 142:5-13. doi:10.1016/S0003-9365(11)80092-8

Björck S et al (1991) Stratigraphic and paleoclimatic studies of a 5500-year-old moss bank on Elephant Island, Antarctica. Arct Alp Res 23:361-374

Bobrov AA, Charman DJ, Warner BG (1999) Ecology of testate amoebae (Protozoa: Rhizopoda) on peatlands in western Russia with special attention to niche separation in closely related taxa. Protist 150:125-136

Bockheim J et al (2013) Climate warming and permafrost dynamics in the Antarctic Peninsula region. Global Planet Change 100:215-223

Booth RK, Lamentowicz M, Charman DJ (2010) Preparation and analysis of testate amoebae in peatland palaeoenvironmental studies. Mires Peat 7:Art. 2

Bramley-Alves J, King DH, Robinson SA, Miller RE (2014) Dominating the Antarctic environment: bryophytes in a time of change. In: Hanson DT, Rice SK (eds) Photosynthesis in bryophytes and early land plants, vol 37 . Springer, Netherlands, pp 309-324

Bramley-Alves J, Wanek W, French K, Robinson SA (2015) Moss $\delta^{13} \mathrm{C}$ : an accurate proxy for past water environments in polar regions. GCB. doi:10.1111/gcb.12848

Charman DJ, Hendon D, Woodland WA (2000) The identification of peatland testate amoebae (Protozoa: Rhizopoa) in peats. Quat Res Assoc Lond

Chown SL et al (2012) Continent-wide risk assessment for the establishment of nonindigenous species in Antarctica. PNAS 109:4938-4943. doi:10.1073/pnas.1119787109

Clarke LJ, Robinson SA, Hua Q, Ayre DJ, Fink D (2012) Radiocarbon bomb spike reveals biological effects of Antarctic climate change. GCB 18:301-310 
Convey P (1996) The influence of environmental characteristics on life history attributes of Antarctic terrestrial biota. Biol Rev Camb Philos Soc 71:191-225

Convey P (2010) Terrestrial biodiversity in Antarctica: recent advances and future challenges. Polar Sci 4:135-147

Convey P (2011) Antarctic terrestrial biodiversity in a changing world. Polar Biol 34:1629-1641

Cook AJ, Fox AJ, Vaughan DG, Ferringo JG (2005) Retreating glacier fronts on the Antarctic Peninsula over the past half-century. Science 308:541-544

Dansgaard W (1964) Stable isotopes in precipitation. Tellus 16:436468. doi:10.1111/j.2153-3490.1964.tb00181.x

Davey MC, Rothery P (1997) Interspecific variation in respiratory and photosynthetic parameters in Antarctic bryophytes. New Phytol 137:231-240

Ehleringer ER, Roden J, Dawson TE (2000) Assessing ecosystemlevel water relations through stable isotope ratio analyses. In: Sala OE, Jackson RB, Mooney HA, Howarth RW (eds) Methods in ecosystem science. Springer, New York, pp 181-198

Ellwood MDF, Northfield RGW, Mejia-Chang M, Griffiths H (2011) On the vapour trail of an atmospheric imprint in insects. Biol Lett 7:601-604. doi:10.1098/rsbl.2010.1171

Farquhar GD, Ehleringer JR, Hubick KT (1989) Carbon isotope discrimination and photosynthesis. Annu Rev Plant Physiol 40:503-537

Fenton JHC (1980) The rate of peat accumulation in Antarctic moss banks. J Ecol 68:211-228

Fenton JHC, Smith RL (1982) Distribution, composition and general characteristics of the moss banks of the maritime Antarctic. $\mathrm{Br}$ Antarct Surv Bull 51:215-236

Fernandoy F, Meyer H, Tonelli M (2012) Stable water isotopes of precipitation and firn cores from the northern Antarctic Peninsula region as a proxy for climate reconstruction. Cryosphere 6:313-330

Gat JR (1998) Stable isotopes, the hydrological cycle and the biosphere. In: Griffiths H (ed) Stable isotopes. BIOS, Oxford, pp 397-407

Gilbert D, Amblard C, Bourdier G, Francez A-J (1998) The microbial loop at the surface of a peatland: Structure, function, and impact of nutrient input. Microb Ecol 35:83-93

Giraudoux P (2014) Data analysis in ecology: R package "pgirmess", 1.5.9 edn. http://perso.orange.fr/giraudoux. Accessed 09 June 2014

Helliker BR, Griffiths H (2007) Toward a plant-based proxy for the isotope ratio of atmospheric water vapor. GCB 13:723-733

IAEA, WMO (2014) Global network of isotopes in precipitation. GNIP database. http://www.iaea.org/water

Jassey VEJ et al (2013) Above- and belowground linkages in Sphagnum peatland: climate warming affects plant-microbial interactions. GCB 19:811-823. doi:10.1111/gcb.12075

Ju L, Yang J, Liu L, Wilkinson DM (2014) Diversity and distribution of freshwater testate amoebae (Protozoa) along latitudinal and trophic gradients in China. Microb Ecol. doi:10.1007/ s00248-014-0442-1

Keeling RF, Piper SC, Bollenbacher AF, Walker JS (2008) Atmospheric $\mathrm{CO}_{2}$ records from sites in the SIO air sampling network. In: Center CDIA (ed). Oakridge, TN

Larsen JN et al (2014) Polar regions. In: Barros VR, Field CB, Dokken DJ, Mastrandrea MD, Mach KJ, Bilir TE, Chatterjee M, Ebi KL, Estrada YO, Genova RC, Girma B, Kissel ES, Levy AN, MacCracken S, Mastrandrea PR, White LL (eds) Climate change 2014: impacts, adaptation, and vulnerability. Part B. Regional aspects. Contribution of Working Group II to the fifth assessment report of the Intergovernmental Panel of Climate Change. Cambridge University Press, Cambridge, pp 1567-1612
Lis G, Wassenaar LI, Hendry MJ (2008) High-precision laser spectroscopy $\mathrm{D} / \mathrm{H}$ and ${ }^{18} \mathrm{O} /{ }^{16} \mathrm{O}$ measurements of microliter natural water samples. Anal Chem 80:293-297

Loader NJ, Robertson I, Barker AC, Switsur VR, Waterhouse JS (1997) An improved technique for the batch processing of small wholewood samples to $\alpha$-cellulose. Chem Geol 136:313-317

Longton RE (1988) Biology of polar bryophytes and lichens. Cambridge University Press, Cambridge

LTER (2014) Palmer station weather daily averages. In: Palmer Station information manager NSF (ed). http://pal.lternet.edu/data

Lucieer A, Turner D, King DH, Robinson SA (2013) Using an unmanned aerial vehicle (UAV) to capture micro-topography of Antarctic moss beds. ITC J 27:53-62

Maechler M, Rousseeuw P, Struyf A, Hubert M, Hornik K (2014) Cluster: cluster analysis basics and extensions. R package version $1.15-2$

Ménot-Combes G, Burns SJ, Leuenberger M (2002) Variations of ${ }^{18} \mathrm{O} /{ }^{16} \mathrm{O}$ in plants from temperate peat bogs (Switzerland): implications for palaeoclimatic studies. Earth Plan Sci Lett 202:419-434

Mieczan T (2009) Ecology of testate amoebae (protists) in peatlands of eastern Poland: vertical micro-distribution and species assemblages in relation to environmental parameters. Ann Limnol 45:41-49. doi:10.1051/limn/09003

Mieczan T, Adamczuk M (2014) Ecology of testate amoebae (protists) in mosses: distribution and relation of species assemblages with environmental parameters (King George Island, Antarctica). Polar Biol. doi:10.1007/s00300-014-1580-0

Mitchell EAD (2004) Response of testate amoebae (Protozoa) to N and $\mathrm{P}$ fertilization in an Arctic wet sedge tundra. Arct Antarct Alp Res 36:78-83. doi:10.2307/1552430

Mitchell EAD, Gilbert D (2004) Vertical micro-distribution and response to nitrogen deposition of testate amoebae in Sphagnum. J Eukaryot Microbiol 51:480-490

Mitchell EAD, Gilbert D, Buttler A, Amblard C, Grosvernier P, Gobat JM (2003) Structure of microbial communities in Sphagnum peatlands and effect of atmospheric carbon dioxide enrichment. Microb Ecol 46:187-199

Mitchell EAD, Charman DJ, Warner BG (2008) Testate amoebae analysis in ecological and palaeoecological studies of wetlands: past, present and future. Biodivers Conserv 17:2115-2137

O'Brien RMG (1974) Meteorological observations on Elephant Island. Br Antarct Surv Bull 39:21-33

Oliverio AM, Lahr DJG, Nguyen T, Katz LA (2014) Cryptic diversity within morphospecies of testate amoebae (Amoebozoa: Arcellinida) in New England bogs and fens. Protist 165:196-207

Parnikoza I et al (2009) Current status of the Antarctic herb tundra formation in the Central Argentine Islands. GCB 15:1685-1693

Payne RJ (2014) A natural experiment suggests little direct temperature forcing of the peatland palaeoclimate record. J Quat Sci 29:509-514

Payne R, Mitchell ED (2009) How many is enough? Determining optimal count totals for ecological and palaeoecological studies of testate amoebae. J Paleolimnol 42:483-495. doi:10.1007/ s10933-008-9299-y

Payne R, Gauci V, Charman DJ (2010) The impact of simulated sulfate deposition on peatland testate amoebae. Microb Ecol 59:76-83

Potter KA, Arthur Woods H, Pincebourde S (2013) Microclimatic challenges in global change biology. GCB 19:2932-2939. doi:10.1111/ gcb. 12257

Proctor MCF (2005) Why do Polytrichaceae have lamellae? J Bryol 27:221-229

R Core Development Team (2014) R: a language and environment for statistical computing. R Foundation for Statistical Computing, Vienna 
Rice SK, Giles L (1996) The influence of water content and leaf anatomy on carbon isotope discrimination and photosynthesis in Sphagnum. Plant Cell Environ 19:118-124

Royles J (2012) Environmental isotopic records preserved in Antarctic peat moss banks. $\mathrm{PhD}$, University of Cambridge, Cambridge

Royles J, Griffiths H (2014) Climate change impacts in polar-regions: lessons from Antarctic moss bank archives. GCB. doi:10.1111/ gcb. 12774

Royles J, Ogée J, Wingate L, Hodgson DA, Convey P, Griffiths $\mathrm{H}$ (2012) Carbon isotope evidence for recent climate-related enhancement of $\mathrm{CO}_{2}$ assimilation and peat accumulation rates in Antarctica. GCB 18:3112-3124. doi:10.1111/j.1365-2486.2012.02750.x

Royles J et al (2013a) Plants and soil microbes respond to recent warming on the Antarctic Peninsula. Curr Biol 23:1702-1706. doi:10.1016/j.cub.2013.07.011

Royles J, Ogée J, Wingate L, Hodgson DA, Convey P, Griffiths $\mathrm{H}(2013 \mathrm{~b})$ Temporal separation between $\mathrm{CO}_{2}$ assimilation and growth? Experimental and theoretical evidence from the desiccation tolerant moss Syntrichia ruralis. New Phytol 197:1152-1160

Royles J, Sime LC, Hodgson DA, Convey P, Griffiths H (2013c) Differing source water inputs, moderated by evaporative enrichment, determine the contrasting $\delta^{18} \mathrm{O}_{\text {CELlulose }}$ signals in maritime Antarctic moss peat banks. JGR Biogeosci 118:184-194. doi:10.1002/jgrg. 20021

Rubino $\mathrm{M}$ et al (2013) A revised 1000 year atmospheric $\delta 13 \mathrm{C}-\mathrm{CO}_{2}$ record from Law Dome and South Pole, Antarctica. JGR Atmos 118:8482-8499

Sageman BB, Bina CR (1997) Diversity and species abundance patterns in Late Cenomanian black shale biofacies, Western Interior, USA. Palaios 12:449-466

Scientific Committee on Antarctic Research (2014) Antarctic climate data: READER project. British Antarctic Survey. http://www. antarctica.ac.uk/met/READER/

Smith RIL (1988) Recording bryophyte microclimate in remote and severe environments. In: Glime JM (ed) Methods in bryology. Hattori Botanical Laboratory, Nichinan, pp 275-284

Smith HG (1992) Distribution and ecology of the testate rhizopod fauna of the continental Antarctic zone. Polar Biol 12:629-634

Smith HG (1996) Diversity of antarctic terrestrial protozoa. Biodivers Conserv 5:1379-1394

Smith HG, Wilkinson DM (2007) Not all free-living microorganisms have cosmopolitan distributions - the case of Nebela (Apodera) vas Certes (Protozoa: Amoebozoa: Arcellinida). J Biogeogr 34:1822-1831

Sternberg L, Ellsworth PFV (2011) Divergent biochemical fractionation, not convergent temperature, explains cellulose oxygen isotope enrichment across latitudes. PLoS One. doi:10.1371/journal.pone. 0028040

Stockmarr J (1971) Tablets with spores used in absolute pollen analysis. Pollen Spores 13:615-621
Swindles GT, Charman DJ, Roe HM, Sansum PA (2009) Environmental controls on peatland testate amoebae (Protozoa: Rhizopoda) in the North of Ireland: implications for Holocene palaeoclimate studies. J Paleolimnol 42:123-140

ter Braak CJF, Šmilauer P (2002) CANOCO reference manual and Canodraw for Windows user's guide: software for canonical community ordination (v. 4.5). Microcomputer Power, New York

Todorov M, Golemansky V (1999) Biotrophic distributon of testate amoebae (Rhizopoda: Testacea) in continental habitats of the Livingston Island (the Antarctic). Bulg Antarct Res Life Sci 2:48-56

Tsyganov AN, Aerts R, Nijs I, Cornelissen JHC, Beyens L (2012) Sphagnum-dwelling testate amoebae in Subarctic bogs are more sensitive to soil warming in the growing season than in winter: the results of eight-year field climate manipulations. Protist 163:400-414

Turner $\mathrm{J}$ et al (2005) Antarctic climate change during the last 50 years. Int J Climatol 25:279-294

Turner J et al (2009) Antarctic climate change and the environment. Scientific Committee on Antarctic Research, Cambridge

Turner $\mathbf{J}$ et al (2014) Antarctic climate change and the environment: 2014 update. Polar Record 50:237-259. doi:10.1017/ S0032247413000296

Vincke S, Ledeganck P, Beyens L, Van De Vijver B (2004) Soil testate amoebae from sub-Antarctic Îles Crozet. Antarct Sci 16:165-174

Vincke S, Van De Vijver B, Gremmen N, Beyens L (2006) The moss dwelling testacean fauna of the Strømness Bay (South Georgia). Acta Protozool 45:65-75

Wasley J, Robinson SA, Turnbull JD, King DH, Wanek W, Popp M (2012) Bryophyte species composition over moisture gradients in the Windmill Islands, East Antarctica: development of a baseline for monitoring climate change impacts. Biodiversity $13: 257-264$

Weisse T, Muller H, Pinto-Coelho RM, Schweizer A, Springmann D, Baldringer G (1990) Response of the microbial loop to the phytoplankton spring bloom in a large prealpine lake. Limnol Oceanogr 35:781-794

West AG, Patrickson SJ, Ehleringer JR (2006) Water extraction times for plant and soil materials used in stable isotope analysis. Rapid Comm Mass Spec 20:1317-1321

Wilkinson DM (2001) What is the upper size limit for cosmopolitan distribution in free-living microorganisms? J Biogeogr 28:285-291

Williams TG, Flanagan LB (1996) Effects of changes in water content on photosynthesis, transpiration and discrimination against ${ }^{13} \mathrm{CO}_{2}$ and $\mathrm{C}^{18} \mathrm{O}^{16} \mathrm{O}$ in Pleurozium and Sphagnum. Oecologia 108:38-46

Yang J, Smith HG, Sherratt TN, Wilkinson DM (2010) Is there a size limit for cosmopolitan distribution in free-living microorganisms? A biogeographical analysis of testate amoebae from polar areas. Microb Ecol 59:635-645 